\title{
MEMOIRS OF ARCHPRIEST N. KARASHEVICH ON THE PILGRIMAGE TO PALESTINE AND TO MOUNT ATHOS IN 1872
}

\author{
Kirill E. Baldin \\ Ivanovo State University, Ivanovo, Russian Federation
}

\begin{abstract}
The article analyzes the memories of one of Russian Orthodox pilgrims, who travelled across the Eastern Mediterranean priest N. Karashevich of the Starokostyantynov town in the Volyn province. The text gives external and internal criticism of these memories, which were printed in 1874 in the Volyn eparchial sheets magazine. The memoirist told about the journey, held in 1872; he visited Jerusalem, Bethlehem and other shrines of Palestine, as well as Mount Athos.

Such category as "the other" is very important in this text, it is nonverbally present in memories describing the various facts, events and phenomena. For the author category "the other" is first and foremost - a Greek Orthodox Church, which was close to the Russian Orthodox Church, but had its differences. The article also addresses the rumors and fears, which had been circulating among Russian pilgrims. They concerned those surprises and dangers, which travelers from Russia could meet on their way.

The article examines the provincial priest perception of another ethno-cultural and religious world, in particular, his attitude towards the Greek Orthodox clergy and Catholics in the Middle East. The author shows the attitude of Russian pilgrims to the holy sites of Mount Athos and its monks, which were considered in Russia a model of piety.

The end of the article contains important conclusion: during the pilgrimage Russian travelers have experienced ethno-cultural and religious identity. They more clearly felt their place in the world as Russians and Orthodox.

Key words: history of Russian Orthodox Church, orthodox pilgrimage, pilgrim memories, Ottoman empire, Palestine, Orthodox clergy, Greek Orthodox churches in the Middle East.

Citation. Baldin K.E. Memoirs of archpriest N. Karashevich on the pilgrimage to Palestine and to mount Athos in 1872. Vestnik Volgogradskogo gosudarstvennogo universiteta. Serija 4, Istorija. Regionovedenie. Mezhdunarodnye otnoshenija [Science Journal of Volgograd State University. History. Area Studies. International Relations], 2017, vol. 22, no. 2, pp. 35-46. (in Russian).
\end{abstract}

\section{МЕМУАРЫ ПРОТОИЕРЕЯ Н. КАРАШЕВИЧА О ПАЛОМНИЧЕСТВЕ В ПАЛЕСТИНУ И НА АФОН В 1872 ГОДУ}

\author{
Кирилл Евгеньевич Балдин \\ Ивановский государственный университет, г. Иваново, Российская Федерация
}

\begin{abstract}
Аннотация. В статье анализируются мемуары одного из российских православных паломников, который путешествовал по Восточному Средиземноморью - священника Н. Карашевича из города Староконстантинова Волынской губернии. Дана внешняя и внутренняя критика источника личного происхождения, сделан акцент на положительные и отрицательные впечатления, которые получил мемуарист в чуждой этноконфессиональной и культурной среде. Делается вывод о том, что в ходе паломничества русские путеше고 ственники проходили этнокультурную и конфессиональную самоидентификацию, более отчетливо ощущая свое место в мире как россиян и православных.

Ключевые слова: история Русской православной церкви, православное паломничество, паломнические мемуары, Османская империя, Палестина, православное духовенство, греческие православные церкви на Ближнем Востоке.
\end{abstract}


Цитирование. Балдин, К. Е. Мемуары протоиерея Н. Карашевича о паломничестве в Палестину и на Афон в 1872 году / К. Е. Балдин // Вестник Волгоградского государственного университета. Серия 4, История. Регионоведение. Международные отношения. - 2017. - Т. 22, № 2. - С. 35-46.

Мемуары паломников в Святую землю (Палестину) представляют собой очень своеобразный и интересный жанр литературы. Такого рода произведения были очень редкими в условиях Средневековья, стали появляться все чаще в российское Новое время, то есть в XVIII - первой половине XIX в., и, наконец, получили весьма широкое распространение во второй половине позапрошлого столетия и в начале XX века. До середины XIX в. они выходили в основном из-под пера любознательных представителей благородного сословия, путешествовавших по Восточному Средиземноморью, но с наступлением эпохи модернизации в Палестину потянулись также преподаватели семинарий и академий, то есть ученое духовенство, а также простые провинциальные священники, как городские, так и сельские. Некоторые из них сто-полтораста лет назад опубликовали свои воспоминания на страницах местных духовных официозов «Епархиальных ведомостей».

Абсолютное большинство этих источников личного происхождения до настоящего времени были прочно забыты как исследователями феномена российского паломничества, так и краеведами. Между тем эти мемуары, а также дневники и письма могут предоставить в распоряжение историков, культурологов, религиоведов ценную информацию о конфессиональной обстановке на Ближнем Востоке, об отношениях между собой русской и греческой православных церквей, о повседневной жизни российских паломников в святых местах, о восприятии ими иного этнокультурного и религиозного мира. Одним из таких мемуаристов является провинциальный священник с Украины Никанор Карашевич.

Об авторе воспоминаний известно очень немногое. Никанор Стефанович Карашевич окончил Волынскую духовную семинарию в 1843 г. и стал служить в уездном городе Староконстантинове Волынской губернии [9]. В 1852 г. тяжело заболела эпилепсией его трехлетняя дочь, но по молитвам отца она выздоровела и отец Никанор дал обет возродить в городе Крестовоздвиженский храм.
В течение года его трудами и энергией были собраны средства и произведены строительные работы, в 1853 г. храм был освящен. В 1872 г. отец Никанор совершил паломничество в Святую землю и на Афон, а в 1874 г. на страницах «Волынских епархиальных ведомостей» появились рассматриваемые нами воспоминания об этой поездке. Как свидетельствуют статистические данные по г. Староконстантинову за 1883 г. в это время отец Никанор Карашевич по-прежнему являлся здесь священником в звании протоиерея [10].

Мемуары Н. Карашевича опубликованы в провинциальном духовном официозе «Волынские епархиальные ведомости». Такого рода журналы начали выходить в России по примеру «Губернских ведомостей» с 1860 -х гг. в епархиях Русской православной церкви. На Волыни их стали издавать с 1866 г. в г. Кременце, типография располагалась по соседству в Почаеве. Как и другие повременные издания такого рода, «Волынские епархиальные ведомости» состояли из официальной и неофициальной частей. Воспоминания Карашевича появились в 1874 г. в четырех номерах подряд в неофициальной части, в каждом номере печатался фрагмент этого источника объемом от 16 до 22 страниц. Название этих путевых записок звучало так: «Записки о путешествии по Св. местам Востока».

Мемуары написаны в основном простым и доходчивым языком, читаются с интересом. При их анализе нужно, во-первых, учитывать социально-профессиональную принадлежность автора: он являлся действующим православным клириком и принадлежал к белому провинциальному духовенству. Во-вторых, его труд был рассчитан на совершенно определенную читательскую аудиторию - представителей духовного сословия, для которого собственно и издавались «Епархиальные ведомости». Их выписывали и получали если не в каждом приходе, то, по крайней мере, в каждом благочинническом округе.

В связи с этим в тексте встречается довольно много архаичной лексики и церковнославянизмов. В частности, свой багаж отец 
Никанор называет «путешественной сумой». Церковь в Одессе, где он надеялся получить временное пристанище на пути в Палестину, он возвышенно именует «пристанищем труждающихся и обремененных». Аналогичная лексика появляется в тексте тогда, когда он описывает главную святыню мирового христианства - храм Гроба Господня в Иерусалиме. Выступая гидом по нему, он с пафосом обращается к читателю: «Внидем (!) сперва в придел бичевания Господа нашего...» [2, с. $723 ; 3$, с. 772$]$.

Автор в тексте ведет заочный разговор с читателем, изредка напрямую обращаясь нему. Предваряя свои путевые записки пространным предисловием, отец Никанор как бы спохватывается и извиняется за это: «Добрые читатели! Не взыщите с меня за несколько утомительное вступление к рассказу о замечательных вещах истории, которые пришлось видеть мне во время моего путешествия» [2, c. 721]. Странствуя по Иерусалиму, автор «виртуально» показывает читателю достопримечательности Святого града; по ходу этой экскурсии он акцентирует прямыми обращениями к читателям особенно интересные памятники священной истории, например: «Теперь, добрые соотечественники, пойдемте в подвал соломонова храма и взглянем на дела рук человеческих, живших до нас почти за 3000 лет» [3, с.781].

При чтении бросается в глаза простота и неискушенность автора. Хотя он не являлся сельским клириком, его менталитет отличался провинциальностью. Местом его духовного служения был г. Староконстантинов уездный центр Волынской губернии. В настоящее время город сохранил свое название и принадлежит к Хмельницкой области Украины. Словосочетание «провинциальное захолустье» вполне подходило к этому городскому поселению.

После путешествия по железной дороге автор, судя по всему, впервые оказался в большом портовом городе - Одессе. Торгово-промышленная жизнь последней была даже более оживленной, чем в Киеве. Одесса, по словам мемуариста, «немало удивила меня своим богатством, красотой, великолепием каменных зданий, изяществом и вкусом постройки домов и в особенности кипучей жизнью и движением торговли». Автор не мог не залюбоваться морем, «широко раскинутым в просторную даль и множеством судов и пароходов разносортных и разнокалиберных, на одном из которых мне предстояло плыть в Константинополь, а оттуда в г. Яффу - предпутье ко Св. Граду Иерусалиму» [2, с. 723].

По простоте душевной отец Никанор направился просить о ночлеге к ближайшей церкви, но Одесса являлась городом многоконфессиональным и первой на его пути встретилась чуждая для него армянская церковь. Когда он, сильно уставший от путешествия, с тяжелым багажом добрался до соборного храма, его также ждал неприятный сюрприз. Первый встреченный им священнослужитель сурово отказал ему, сославшись на то, что для ночлега требуется разрешение соборного ключаря. Как видно, порядки в крупном городе были не такими патриархальными, как в уездной глуши на Волыни. Пришлось пройти еще около версты до гостиницы, где автор обрел временный приют до отправления судна $[2$, c. 723-724].

Большое беспокойство ему причиняла предстоящая поездка по морю, которая страшила его своей новизной и опасностью. От кого-то он узнал, что весной и осенью (он отправился в путешествие в марте) Черное море особенно неспокойно. Н. Карашевичу пришлось много времени провести в молитве, чтобы успокоиться душой. Кроме того, он сходил в Одессе в церковь во имя святого Николая Чудотворца - покровителя путешествующих по водам. Автор сообщает, что молитва здесь укрепила его веру в счастливый исход путешествия [2, с. 724].

Когда полоска родной земли скрылась из глаз, «опять было приуныло сердце». Однако оказалось, что пароход, несмотря на волнение, вовсе не собирается тонуть. Кроме того, автор и его спутники видели, что «начальствующие над судном» абсолютно спокойно выполняют свои профессиональные обязанности. Это вселило уверенность в русских паломников, которые находились на корабле, и в дальнейшем автор охотно говорит о тех судах, на которых ему приходилось путешествовать. Для справки отметим, что из Одессы в Константинополь их доставил российский пароход «Буг». На этом общение паломников с 
отечественным пассажирско-торговым флотом и закончилось. Из Константинополя в Яффу шел австрийский пароход, обратно до пролива Дарданеллы - тоже, и билет на него покупали в специальном австрийском агентстве в Яффе. От пролива до Афона, а затем в Константинополь русские паломники путешествовали на турецком судне. В столице Ocманской империи они пересели до Одессы на итальянский пароход, который, по словам восхищенного мемуариста, был «великолепного новейшего устройства» $[2$, с. $725,726,730 ; 4$, c. 818,$820 ; 5$, c. $841-842]$.

От себя заметим, что радоваться и восхищаться было нечему. Как следует из текста, не только на Средиземном, но и в значительной степени на Черном море курсировали на торгово-пассажирских линиях пароходы, ходившие под иностранными флагами. Еще в 1856 г. было создано Русское общество пароходства и торговли (РОПИТ), призванное противостоять иностранному засилью в судоходстве. Оно начинало свою деятельность с пяти пароходов, а в 1869 г. уже эксплуатировало 63 судна, которые в том же году совершили 2867 рейсов, перевезли 430 тыс. пассажиров, не считая большого количества коммерческих грузов. РОПИТ на регулярной основе обслуживал 20 линий, из них 6 международных, в том числе в Константинополь, Александрию, Марсель, Лондон. Никанор Карашевич воспользовался судном этой кампании под названием «Буг» (мощностью 144 лошадиных сил и в 1800 тонн водоизмещения) для того, чтобы добраться от Одессы до турецкой столицы [14]. В дальнейшем его вместе с его спутниками перевозили иностранные пароходы.

Таким образом, отец Никанор то ли по простоте душевной, то ли по недостатку информированности не проявил того патриотизма, которого можно было бы от него ожидать. Вместо того чтобы посетовать на отсутствие российских пароходов на линиях в Восточном Средиземноморье и тем более в Черном море, он наивно восхищался иностранным судном. Забегая вперед, отметим, что на рубеже XIX-XX в. российские пароходы уже обслуживали рейсы от Одессы до Яффы и Александрии, доставка паломников в Святую землю стала важным направлением пассажирского сегмента деятельности РОПИТ.
Наряду с простотой, безыскусностью мемуариста сквозь строчки просматривается его искренняя религиозность. Упоминание имени Бога встречается на страницах мемуаров очень часто. Путешествие на Ближний Восток для отца Никанора было обетным: он обещал Богу отправиться ко Гробу Господню в трудный момент, о котором он в мемуарах умалчивает: «Но я считаю долгом, прежде всего, заметить, что мое путешествие по св. местам Востока не было следствием одного любопытства; нет, оно вытекало из глубокой душевной потребности исполнить обет, данный Господу Богу в трудных обстоятельствах моей жизни. Преследуемый с юности и доныне общим врагом человечества - дьяволом, я ни в ком и никогда не полагал моего упования, исключая одного Бога. В нем одном находил отраду, помощь и спасение и только по Его неисповедимой благости “есмь еже есмь"» [2, с. 721$]$.

К Богу автор обращается и для того, чтобы поблагодарить его за получаемые блага, и в минуты уныния. Например, приехав в Одессу и увидев неспокойное море, автор впал в грех уныния. Однако спасла и приободрила автора все та же крепкая вера, он воспрянул духом: «К этому расположил меня Тот Самый Верховный укротитель стихий, Который во время оно подал руку помощи утопавшему Ап. Петру. Он всеблагий и мне грешному указал на прибрежный храм Святителя и чудотворца Николая, в котором, помолившись перед отплытием, я совершенно разогнал в себе мглу боязни, смущавшую меня» [2, с. 724].

Совершенно особенные слова мемуарист находит для описания своего пребывания в святынях вселенского христианства. Вот как эмоционально переживал он свой первый приход в храм Гроба Господня: «Что чувствовало мое сердце и в каком состоянии была душа, когда я прикладывался к ложу Господа, одетому беломраморной доской, из-под которой самым ощутительным образом исходит райское благовоние - этого передать я не в состоянии... Я долго не мог оторваться от этого тихого пристанища, читая самые умилительные, молитвы и изливая обильные струи слез, которые в этом святом месте даются свыше каждому почти молящемуся как целебный бальзам в сокрушении сердечном» [2, с. 736$]$. 
Текст мемуаров представляет собой довольно интересно изложенную информацию о тех местах на Ближнем Востоке, где побывал автор. В целом изложение носит чисто описательный характер, оно прерывается только эмоционально окрашенными рассуждениями о христианских святынях, которые встречаются на пути автора. Только один раз в мемуарах встречается небольшая справка, посвященная истории Иерусалима. Судя по ее содержанию, она представляет собой сводку тех сведений, которые любой внимательный читатель может обнаружить на страницах Ветхого Завета [3, c. 266-267]. Автор не пользовался какой либо научной литературой при написании мемуаров, впрочем, этого не стоило ожидать от простого провинциального иерея, имевшего только семинарское образование и являвшегося не ученым богословом, а «практиком». В тексте также нет видимых следов использования даже обычных путеводителей.

Для сравнения обратимся к другим мемуарам, написанным посетившим Палестину в 1890-х гг. священником Евгением Мерцаловым, они называются «От Петрозаводска до Иерусалима и обратно» [12]. Эти мемуары снабжены многочисленными ссылками на источники личного происхождения, прочитанные автором, и на научную литературу, проштудированную им. Он очень часто цитирует «Хождение» игумена Даниила в Палестину (первого русского паломника XII в.) в Святую землю, оставившего свои путевые записки [12, c. $138,156,160,201,203,217-218,229,232$, 240]. Отец Евгений знал литературу эпохи Древнего мира, в частности христианского богослова Евсевия Кесарийского [12, с. 137, 160, $179,191,228,240]$, работы русского палестиноведа и профессора Киевской духовной академии А.А. Олесницкого [12, с. 196-197, $243-$ 244]. Он же внимательно прочел воспоминания о паломничестве в Палестину своих предшественников - А.С. Норова [12, с. 57, 125, $141,146,205]$ и др. Е. Мерцалов, в отличие от Н. Карашевича, имел академическое образование. Будучи выпускником Киевской духовной академии, он преподавал в Олонецкой духовной семинарии - соответственно, его общекультурный и богословский кругозор был значительно шире, чем у простого священника $[12$, с. 7-8].
Хотя автор не пользовался путеводителями или же умалчивает об этом, сами мемуары отца Никанора представляют собой своеобразный путеводитель по святым местам. В самом начале своего повествования он информирует о необходимости получить разрешение на паломничество от епархиального владыки. Далее потенциальные путешественники могли узнать о том, что по пути они имеют возможность остановиться в Одессе в гостинице при местном архиерейском доме, а в Константинополе - на подворьях афонских монастырей и что заграничный паспорт можно оформить в Одессе за один день [2, с. 722, 724]. В дальнейшем автор сообщает «добрым читателям», где можно остановиться на ночлег в палестинском порту Яффа и в самом Иерусалиме. В первом случае - это российское консульство, а во втором - русская гостиница [2, с. 734,735$]$. Таким образом, отец Никанор осуществлял информационное сопровождение паломников в святые места.

Мемуары напоминают путеводитель, потому что автор подробно останавливается на описании святынь вселенского христианства, которые входят в неофициальный, но почти обязательный список для посещения любого паломника. Особенно подробно он описывает главную святыню Иерусалима храм Воскресения Христова. Он повествует не только о часовне Гроба Господня и Голгофе, но и всех приделах, которые здесь имелись (приделы бичевания Господа, Богородицы, Логгина Сотника и др.). Речь в анализируемом нами тексте идет и о других святынях города: храмах Константина и Елены, монастырях: Никольском, во имя Иоанна Предтечи и др. Автор не ограничивается общехристианскими и православными святынями, он сообщает информацию о посещенных им инославным объектах - католических монастырях и армянской патриархии. При этом сообщается не только о внешнем виде культовых сооружений и их внутреннем убранстве. Автор, памятуя, что его записки станут достоянием гласности, объясняет, как пройти к этим объектам по довольно запутанной сетке иерусалимских улиц и переулков [3, с. 768-780]. То же самое касается не только Иерусалима, но и других святынь Палестины и Афона. 
По страницам мемуаров отца Никанора разбросаны в большом количестве хронотопы Святой земли. Это пространственно-временные связи, которые касаются двух пластов священной истории - библейского и евангельского. Автор путешествовал по различным священным местам и рассказывал соответствующие новозаветные и ветхозаветные сюжеты, которые у него четко привязаны к определенным местам. Одним из таких хронотопов был город Ларнак на острове Кипр, где на некоторое время высадились русские паломники. В алтарной части местной церкви покоились мощи друга Иисуса Христа - Лазаря, воскрешенного Спасителем. Автор отслужил молебен этому святителю [2, с. 731]. Другим примером хронотопа являлся Гефисманский сад, в котором происходило евангельское моление о чаше, здесь же Иисус был предан Иудой. Особое внимание автора в этом священном месте привлекли вековые деревьямаслины. Они были, по выражению отца Никанора, «отродьями» тех деревьев, под которыми молился Спаситель [3, с. 785]. Относительно Крестного монастыря рядом с Иерусалимом автор не преминул упомянуть, что здесь было срублено дерево, из которого изготовили крест для распятия Христа [4, с. 809].

Несмотря на простоту автора и его молитвенные восторги в святых местах, он в самом конце мемуаров предстает перед нами как человек весьма практичный. Три из четырех приложений представляют собой рекомендации потенциальным паломникам в Святую землю и на Афон. Здесь автор предлагает читателям оптимальный маршрут путешествия, который предполагает, что поклонники посетят все основные святыни и застанут здесь важные для любого христианина Великий пост и Пасху, нигде не задерживаясь. Этот маршрут предусматривал их выезд из России на Масленицу, пребывание на Афоне в течение первых трех недель Великого поста, а затем путешествие в Палестину с целью встретить Пасху в Иерусалиме на месте Воскресения Христова [5, с. 853].

Практичность автора особенно рельефно видна в приложении, носящем название «О количестве денежного и продовольственного содержания, необходимого для путешествия по св. местам Востока». В нем подроб- но перечисляются расходы, которые мемуарист понес во время путешествия. В числе их упоминается стоимость пароходных билетов Одесса - Константинополь (4 руб.) и Константинополь - Яффа (11 руб.), оформление заграничного паспорта (2 руб. 20 коп.), плата за гостиницы в различных городах, расходы на пожертвования и т. д. По расчетам автора, для путешествия вполне хватит 90 руб., а если взять в дорогу побольше сухарей и питаться ими, то можно обойтись даже 70 руб. Из этих расчетов автор делает однозначный и ободряющий для будущих паломников вывод о том, что путешествие в Святую землю вполне доступно не только для провинциального священника, но и для крестьянина среднего достатка $[5$, с. 852$]$.

На страницах мемуаров Никанора Карашевича отчетливо прочитываются такие социологические и одновременно психологические категории, как слухи и страхи. Слухи представляли собой устную народную информацию, в которой реальные события и явления порой трансформировались до неузнаваемости. Слухообразующими элементами, то есть «кирпичиками» информации становились экстраординарные события, необычные люди, отличавшиеся от русских по внешности, поведению и менталитету.

Автор говорит, что еще у себя на родине слышал, что Черное море особенно неспокойно во время осеннего и весеннего равноденствия, а именно на март выпадало его путешествие из Одессы к берегам Палестины. Этот слух по прибытии в Одессу быстро превратился у автора в страх, как только он увидел море, судя по всему - первый раз в жизни. Он пишет в воспоминаниях, что у него «заныло сердце, и много-много употребил я усилий, пока ободрился духом». Страх был вполне естественным и не только потому, что он основывался на слухе, но и потому, что Н. Карашевич был человеком сугубо сухопутным. Ему удалось побороть страх только с помощью веры после молитв Спасителю, а также святому Николаю Угоднику - покровителю всех путешествующих по водам [2, с. 724].

Страх по тому же поводу не раз повторился, так как путешествие было длительным. Второй раз боязнь охватила волынского батюшку вскоре после отплытия из Одессы: 
«Судно понеслось быстро, и Одесса скрылась от наших взоров. Вот теперь прости, земля родная, подумал я про себя, очутившись на безбрежной воде под открытым небом, где не слышно ничего, кроме плеска волн о бока судна, где не видно ничего, кроме неба и воды. Опять было приуныло сердце». На этот раз приступ страха был погашен тем, что «начальствующие над пароходом» (то есть капитан и команда) вели себя спокойно и уверенно, внушая своим поведением чувство безопасности пассажирам [2, с. 725].

Страшной показалась пассажирам высадка на берег в Яффе, хотя, казалось бы, они должны были быть счастливы от прибытия в Святую землю. Гавани в Яффе не было, и пароходы останавливались далеко от берега. Несмотря на волнение на море, к судну быстро приблизились лодки с арабами-перевозчиками. По знаку капитана они хватали не ожидавших этого пассажиров буквально в охапку и вместе с их багажом сажали в свои утлые суденышки. На всю жизнь автору запомнилась эта сцена, сопровождаемая криком и бранью паломников, лодочников и матросов [2, с. 733].

На слухах, во многом справедливых, основан был страх паломников перед теми, кого автор назвал «хищными арабами, бедуинами и иными кочевыми народами». Страх возник, по всей вероятности, в результате рассказов проводников, которые любили разные «страшилки» и обращали внимание поклонников на то, что большинство христианских святынь в Палестине представляют собой укрепления, которые могли выдерживать длительные осады местных вооруженных племен [4, с. 814]. $\mathrm{B}$ соответствии с имеющейся классификацией слух о «хищных арабах» может быть квалифицирован как слух-пугало. Это были, как правило, неофициальные сведения о жестоких штормах, бушующих на морях, об агрессивном и фанатичном местном населении Палестины и т. д. Существовали также слухи-желания, то есть индивидуальное или коллективное стремление к какой-либо цели, чаще всего имеющей благой характер. К этой категории можно отнести распространенный среди русских паломников слух о том, что когда-нибудь на храме святой Софии в Константинополе, превращенном турками в мечеть, будет водружен православный крест. Что касается еще одной категории - агрессивных слухов, то они не были распространены среди православных паломников, являвшихся людьми сугубо мирными [11].

В мемуарах почти всех паломников, направлявшихся в Палестину и на Афон, зримо присутствует категория Другого. В социологической науке различаются два ее вида. Вопервых, это значимый Другой, о котором у рефлексирующего субъекта имеется определенная информация. Во-вторых, это обобщенный Другой, о котором сведений нет или они не очень недостоверны, будучи основаны не на точном знании, а на слухах.

Категория Другого может быть как со знаком плюс, так и со знаком минус. Русские паломники имели более ими менее точные сведения о том, что они едут в иные края, расположенные в другом культурном пространстве и в другом климатическом поясе. Источники этого знания были письменными или устными - путевые записки предшественников, либо рассказы бывалых паломников. Информация эта представлялась отрывочной, поэтому столкновение с реалиями Ближнего Востока порой было неожиданным. Характерно, что в мемуарах о. Никанора ничего не говорится о жарком климате, особенностях флоры и фауны. Вероятно, он считал это суетным, а, следовательно, ненужным и даже не достойным появления на страницах своих записок.

Первым необычным и никогда не испытанным до тех пор ощущением стала тривиальная морская болезнь, которой страдал не выходивший ни разу в море отец Никанор. Он постепенно усиливалась, сопровождалась тошнотой и полной потерей аппетита. Без пищи автор оставался двое суток и с большим трудом пережил эти испытания. «Утешение и помощь» пришли от его попутчика - афонского иеромонаха отца Паисия, который «с ангельской заботливостью» ухаживал за отцом Никанором [2, с. 725].

В дальнейшем Другое выглядело на страницах мемуариста гораздо более привлекательно и чаще всего оно ассоциировалось с греческой православной церковью. Русским паломникам обязательно приходилось сталкиваться с ее рядовыми клириками и епископа- 
том. В этом отношении характерны строки, описывающие краткое пребывание русских на пути из Яффы в Иерусалим в местечке Лидда. Здесь «добрые греческие монахи» (слова Н. Карашевича) приняли русских как старых знакомых и угостили фруктами. В дальнейшем положительное отношение к грекам Афона, Константинопольского и Иерусалимского патриархатов как к «единоверным эллинам» не меняется на протяжении всего текста воспоминаний [2, с. $734 ; 5$, с. 835$]$.

Не у всех мемуаристов единоверные греки выглядят «добрыми». Известный русский путешественник А.В. Елисеев, несколько раз посетивший Палестину и хорошо знавший ее реалии, громко сетовал на широкое распространение католичества и лютеранства в Святой земле и, на наш взгляд, совершенно справедливо бросал упрек в этом греческому духовенству: «Как и повсюду в Палестине, греческие монахи не оказались здесь на высоте своего призвания, не сумели поддержать падавшего православия и допустили проделать в нем значительные бреши» [6, с. 347]. Действительно, сотни и тысячи местных православных арабов во второй половине XIX в. под влиянием западной религиозной пропаганды перешли в «латинство» или лютеранство.

Первый раз единение с сестринской греческой церковью Н. Карашевич, а вместе с ним и другие русские паломники испытали буквально на третий день путешествия, оказавшись в чуждой и где-то даже враждебной турецкой столице. Здесь они нашли в мусульманском море единоверный островок в греческой церкви Балаклии, где отцу Никанору позволили отслужить на русском языке молебен о здравии российского императора, всей царствовавшей семьи Романовых и членов российского Святейшего синода. Сделать это в чуждом окружении было очень важно для русских [2, с. 728]. С.Ю. Житенев в этой связи отмечал, что социальная сущность паломничества тесно коррелируется с процессами религиозной самоидентификации [7, с. 156].

Особенно значимым для русских паломников было посещение иерусалимского патриарха. В русской иерархии не было предстоятеля церкви с таким титулом, поэтому паломники отнеслись к нему со всем возможным пиететом. До аудиенции они были прият- но поражены тем, что патриарший архидиакон отец Гавриил неплохо знает русский язык. Беседа с патриархом шла через переводчика, во время нее мемуарист подарил главе Иерусалимской церкви икону Почаевской Богоматери [2, с. 737].

Как большую честь для себя автор воспринял предложение патриарха участвовать совместно с ним в богослужении в Воскресенском храме, причем в Вербное воскресение и на второй день Пасхи. Простой провинциальный батюшка из украинской глубинки был вне себя от счастья и не преминул в мемуарах упомянуть, что с ним в сослужении находились восемь архиепископов, четыре архимандрита, двенадцать иеромонахов и три архидиакона [2, с. 738].

Другое не было бы Другим, если бы оно не отличалось от того, что представлялось для мемуариста привычным. Отправляясь на Ближний Восток, паломники, особенно духовного звания, хорошо знали, что здесь им придется столкнуться с греческими церквями Иерусалимской, Константинопольской, Антиохийской, Александрийской. Паломники догадывались о том, что хотя они являлись православными структурами, но различия, обусловленные историческими причинами, между ними и российской церковью имеются. Причем эти различия находились не в «концептуальной» сфере, а в обрядовой.

Эти особенности лежали на поверхности и в первую очередь бросались в глаза мемуаристу. Во время церемонии, сопровождавшей схождение святого огня в ночь на Пасху, они были настолько Другими, то есть любопытными и необычными, что отец Никанор посвятил им самое большое по объему приложение к своим воспоминаниям - «О святом огне и благодати». Перед схождением огня в храм Гроба Господня пришедшие сюда арабы с громкими криками начали бегать вокруг кувуклии (часовни) Гроба. Их радостные возгласы автор перевел на русский язык так: «Турок верой не хорош, армянин верой не хорош, католик верой не хорош, только араб и греков вера хороша, тверда и несокрушима». Турецкая охрана храма и солдаты пытались утихомирить их, но они в состоянии эйфории даже не чувствовали боли от наносимых им ударов [5, с. 843-845]. Отношение автора к 
этому эпизоду выглядит двояким. С одной стороны, для него поведение арабов выглядит неадекватным, так как одним из правил богослужения в России являлись соблюдение тишины и благочиния. С другой стороны, автор не склонен серьезно осуждать излишне шумных приверженцев православия. Для него они не более чем дети природы, которые выражают свой религиозный восторг привычным для них способом.

Автор немало удивлялся тому, какие Другие, то есть оригинальные обычаи существовали у единоверных эллинов, как в религиозной, так и в мирской жизни. Во время остановки в Смирне на пути в Иерусалим он наблюдал, как во время службы в православном храме молодые греки стреляли постоянно в его дворе из ружей. Автор предположил, что это делается для придания службе большей торжественности, сам же в душе был убежден, что это лишнее [2, с. 731].

В рассматриваемых нами мемуарах почти нет упоминаний о природе, которая в Палестине и на Афоне была более чем Другой по сравнению с Россией. В частности, автор не упоминает об особенностях климата, флоры и фауны Ближнего Востока. Вероятно, он считал такого рода материал слишком мирским, приземленным и не достойным для жанра паломнических записок. Но другие паломники из России не ограничивали себя подобными тематическими рамками. Архимандрит А. Капустин, который долгое время возглавлял Русскую духовную миссию в Иерусалиме, в описании своего первого путешествия в Святую землю в 1857 г. постоянно жаловался на жару, которая в летний сезон была особенно изнурительна для обитателей умеренного климатического пояса. На страницах его воспоминаний постоянно встречаются упоминания о том, что «...солнце палило июльским зноем», «...духота гнала вон из комнаты», «...не смогши заснуть от духоты в своем... нумере» [8, с. 12, 179].

Для мемуаров Никанора Карашевича характерна ярко выраженная бесконфликтность. На их страницах почти нет отрицательных характеристик, критики того, что он видел во время своего путешествия. Это объясняется в первую очередь не особенностями характера автора, а особенностью эпохи, в которой он жил. Во-первых, всего около полутора десятилетий минуло с окончания николаевского царствования, отличавшегося жестким преследованием всего, что выходило за рамки, заданные властью. Всего около десятилетия минуло после того, как было отменено в стране крепостного право. Что особенно важно, в 1872 г., когда было совершено путешествие мемуариста, уже закончился общественный подъем 1860-х годов. Поэтому работник «идеологического фронта», священник Карашевич предпочитал не выступать с критикой, руководствуясь беспроигрышным принципом «как бы чего не вышло...». Хотя несколько небольших исключений из этого правила на страницах мемуаров все же можно отыскать.

Одно из немногих критических замечаний адресовано живописцу, расписывавшему греческую церковь в Балаклии (Константинополь). Он отмечает, что у художника «кисть не очень изящна». Учитывая боязливость автора в высказывании своего мнения и стремление сглаживать острые углы, можно предположить, что живопись здесь была действительно скверной [2, с. 728].

Мемуары многих других паломников отличаются значительно большей критической заостренностью. Так, анонимный автор описания паломничества в Святую землю Арсения, епископа Волоколамского, посетивший вместе с этим архиереем святые места в Восточном Средиземноморье, высказывал возмущение по поводу того, что турки исказили архитектурный облик храма святой Coфии в Константинополе, обстроив его минаретами и неуклюжими контрфорсами. Свои впечатления после посещения этой бывшей православной святыни, превращенной в мечеть, тот же автор суммировал следующим образом: «...мы со скорбным чувством ушли из опустошенной, заброшенной, но еще грандиозной Софии» [1, с. 525, 531].

В целом ряде мемуаров Другое, снабженное совершенно однозначным знаком минус, превращается в Чужое, которое воспринимается русскими паломниками как однозначно неприемлемое и даже враждебное. Известный русский путешественник А.С. Норов в величайшей христианской святыне храме Гроба Господня «...тотчас при входе, в ложе привратника, увидел... сидящих, под- 
жав ноги, турок, с трубками во рту и играющих в шахматы». Поэтому не случайно при молитве в этом храме он произнес: «Господи, ...страдания Твои еще не прекратились! Крещеные святым Твоим Именем и искупленные Тобой владеют этим миром, а нечестивые стерегут святилища Твои!» [13, с. 44].

Будучи православным человеком, отец Никанор, тем не менее, не упустил возможности посетить святыни, которые были связаны с земной жизнью Спасителя, Богоматери и их окружения, но принадлежали иным христианским конфессиям. Здесь категория Другого предстает перед читателями более рельефно, чем при описании богослужебных особенностей в греческих церквях. В Иерусалиме автор осмотрел католические монастыри: францисканского ордена и монастырь во имя Иоакима и Анны. Он также сходил на экскурсию в армянскую патриархию, где присутствовал на службе предстоятеля армянской церкви, обратив внимание, что «перстосложение и рукодвижение» у армян делается по западному образцу. Несмотря на то что эта служба велась в пасхальный праздник, она проходила в полном молчании, которое, по наблюдению отца Никанора, «для нас православных показалось скучным в особенности в такой всерадостнейший день» [3, с. 778-781]. Это еще один из немногих случаев в мемуарах Карашевича, когда он счел нужным отклониться от принципиальной безоценочности своего изложения.

Категория Другого всплывает при описании посещения автором важнейшей христианской святыни - Гефсисманского сада, разделенного на две части. Одна из них принадлежала католикам, и автор вынужден признать, что латиняне ее содержали очень аккуратно, пространство было окружено каменной стеной. Второй частью сада владели православные греки, она была огорожена только со стороны дороги. Несмотря на это, для отца Никанора Другой все же является католическая часть, а некоторая запущенность пространства, принадлежавшего грекам, по его словам «придает месту больше патриархальности и внушает историческую меланхоличность» [3, с. 785-786]. Очевидно, автор не нашел более подходящих слов, чтобы оправдать «единоверных эллинов» за недостаточную заботу о святыне.
Автор обратил внимание на отличия в обрядовой практике, существовавшие на Афоне, хотя русские монастыри на Святой горе и на родине автора относились к одной и той же церкви. Афонская служба, афонские иконы, различного рода священные сувениры со Святой горы всегда считались в России особо благодатными. Служба на Афоне отличалась подчеркнутой истовостью, тщательностью и длилась дольше, чем в российских храмах. Если обращаться к рассматриваемой нами категории Другого, то здесь она отличалась от того, что мемуарист видел на родине, однозначно в положительную сторону. Сигналом к святогорской службе служило то, что монахи сначала около четверти часа били в деревянную доску, потом - в большой колокол и, наконец, четверть часа продолжался трезвон всех колоколов обители. Затем иеродиаконы в церкви очень тщательно в продолжение целого часа кадили весь храм, всех стоящих в нем и каждого в отдельности. Столь же продолжительно и истово отправлялись и другие части литургии. Необычным и немного страшноватым для автора показался способ захоронения афонских монахов. Их останки через несколько лет после смерти извлекали из земли, черепа расставляли на полках с написанными на них именами «владельцев», а все прочие кости складывали в огромный ящик $[5$, c. $835,838-839]$.

Источники личного происхождения - воспоминания, дневники, письма являются самым колоритным и интересным сегментом в общем источниковедческом комплексе проблем исторической науки. Делопроизводственные документы, сухие цифры статистики не могут сравниться с мемуарами по живости восприятия событий и явлений окружающей жизни. В то же время профессиональные историки хорошо знают, насколько обманчивыми порой бывают источники личного происхождения, в которых как сами факты, так и их интерпретация бывают очень субъективными. Не менее опасно доверять на первый взгляд объективным и безоценочным воспоминаниям, таким как мемуары Н. Карашевича, так как автор склонен скрывать те или иные противоречия, с которыми встречался на своем пути, сглаживать острые углы. В результате читатель получает если не искаженную, то неполную информацию. 
Большинство воспоминаний, дневников и эпистолярных источников представляются интересными, но в узко понимаемом практическом плане они не представляют интереса для их читателей. В этом отношении мемуары отца Никанора являются довольно редким исключением. В подзаголовке их названия отсутствует слово «Путеводитель», автор не претендовал на то, чтобы его путевые впечатления относились к этому жанру. Однако «хождение» отца Никанора в Святую землю и на Святую гору обогатило его опытом, которым он поспешил поделиться с любознательными читателями, среди которых были и потенциальные паломники в святые места. В тексте указаны святыни вселенского христианства и православия, которые обязательно нужно или целесообразно посетить, обозначены пути подхода к ним. Автор приводит довольно точную калькуляцию расходов, которые ожидали паломников с разбивкой их на отдельные статьи, а также указывает время года, в которое лучше всего совершить паломничество с привязкой к значимым событиям церковного календаря (Великому посту и Пасхе). В мемуарах уделяется внимание и соображениям безопасности, которые были немаловажными в иноверной для русских Османской империи.

Мемуары Н. Карашевича были написаны типичным представителем российского провинциального духовенства, и это наложило особый отпечаток на рассмотренный нами текст. В отличие от светских паломников, попадавших в Палестину, в мемуарах Карашевича, как, впрочем, и в других известных нам воспоминаниях священников и монашествующих лиц, обращается особое внимание на мельчайшие подробности устройства христианских святынь, на ритуальную сторону религиозного культа, на обрядовые и иные отличия русской и греческой православных церквей. Значительно меньше священники-мемуаристы уделяли внимание красотам природы, климату, пище, способам передвижения.

Полученные во время путешествия к христианским святыням опыт и впечатления позволили отцу Никанору, как и другим паломникам, пройти важный процесс самоидентификации. Посетив дальние страны и увидев отличия их конфессионального пространства от того, что он на время оставил в России, он в большей степени ощутил себя человеком русским и православным. Таким образом, идентификация паломников имела как религиозный, так и этнокультурный характер.

\section{СПИСОК ЛИТЕРАТУРЫ}

1. В стране священных воспоминаний (описание путешествия в Св. Землю, совершенного летом 1900 года Арсением, епископом Волоколамским, Ректором Московской Духовной Академии в сопровождении некоторых профессоров и студентов) // Богословский Вестник. - 1901. - Т. 1, № 3.С. 493-531 (2-я пагинация).

2. Волынские епархиальные ведомости. Часть неофициальная. - 1874. - № 20.

3. Волынские епархиальные ведомости. Часть неофициальная. - 1874. - № 21.

4. Волынские епархиальные ведомости. Часть неофициальная. - 1874. - № 22.

5. Волынские епархиальные ведомости. Часть неофициальная. - 1874. - № 23.

6. Елисеев, А. В. По белу-свету. Очерки и картины из путешествия по трем частям старого света : в 4 т. / А. В. Елисеев. - СПб. : Издание П.П. Сойкина, 1904. - Т. II. - 364 с.

7. Житенев, С. Ю. Религиозное паломничество в христианстве, буддизме и мусульманстве: социокультурные, коммуникативные и цивилизационные аспекты / С. Ю. Житенев. - М. : Индрик, 2012. $-264 \mathrm{c}$.

8. Капустин, А. Пять дней на Святой земле и в Иерусалиме в 1857 году / А. Капустин. - М. : Индрик, 2007. $-236 \mathrm{c.}$

9. Карашевич Никанор Стефанович. - Электрон. текстовые дан. - Режим доступа: http:// www. rosgenea.ru (дата обращения: 19.09.2016). - Загл. с экрана.

10. Крестовоздвиженский мужской монастырь г. Староконстантинова. - Электрон. текстовые дан. Режим доступа: http://www. azbuka.ru/palomnik (дата обращения: 19.09.2016). - Загл. с экрана.

11. Латынов, В. В. Слухи: социальные функции и условия появления. - Электрон. текстовые дан. - Режим доступа: http://www.psyfactor.org/lib/ rumors $3 \mathrm{htm}$ (дата обращения: 13.11.2014). - Загл. с экрана.

12. Мерцалов, Е. От Петрозаводска до Иерусалима и обратно. Путевые заметки и впечатления паломника / Е. Мерцалов. - М. : Индрик, 2014. $256 \mathrm{c}$.

13. Норов, А. С. Путешествие в Святую землю в 1835 году / А. С. Норов. - М. : Индрик, 2008. $292 \mathrm{c}$. 
14. Скальковский, А. Русское Общество пароходства и торговли. 1857-1869 гг. - Электрон. текстовые дан. - Режим доступа: http://www. odessitclub. org/publications/almanac/alm_40/alm_6-19.pdf(дата обращения: 16.09.2016). - Загл. с экрана.

\section{REFERENCES}

1. V strane svyashchennykh vospominaniy (opisanie puteshestviya v Sv. Zemlyu, sovershennogo letom 1900 goda Arseniem, episkopom Volokolamskim, Rektorom Moskovskoy Dukhovnoy Akademii v soprovozhdenii nekotorykh professorov i studentov) [In the Land of Sacred Memories (Description of the Trip to St. Land in Summer of 1900 by Arseny, Bishop of Volokolamsk, Rector of the Moscow Theological Academy, Accompanied by Some Professors and Students)]. Bogoslovskiy Vestnik, 1901, vol. 1, no. 3, pp. 493-531. (2nd pagination).

2. Volynskie eparkhialnye vedomosti. Chast neofitsialnaya [Volyn Eparchial News. Informal Part], 1874, no. 20.

3. Volynskie eparkhialnye vedomosti. Chast neofitsialnaya [Volyn Eparchial News. Informal Part], 1874 , no. 21 .

4. Volynskie eparkhialnye vedomosti. Chast neofitsialnaya [Volyn Eparchial News. Informal Part], 1874, no. 22.

5. Volynskie eparkhialnye vedomosti. Chast neofitsialnaya [Volyn Eparchial News. Informal Part], 1874, no. 23.

6. Eliseev A.V. Po belu-svetu. Ocherki i kartiny iz puteshestviya po trem chastyam starogo sveta. $V 4 t$. T. 2 [Around the Wide World. Stories and Pictures from the Trip to Three Parts of the Old World. In 4 vols. Vol. 2]. Saint Petersburg, P.P. Soykin Publ., 1904. 364 p.
7. Zhitenev S.Yu. Religioznoe palomnichestvo $v$ khristianstve, buddizme i musulmanstve: Sotsiokulturnye, kommunikativnye i tsivilizatsionnye aspekty [Religious Pilgrimage in Christianity, Buddhism and Islam: Socio-cultural, Communicative and Civilizational Aspects]. Moscow, Indrik Publ., 2012. $264 \mathrm{p}$.

8. Kapustin A. Pyat dney na Svyatoy Zemle $i v$ Ierusalime $v 1857$ godu [Five Days in the Holy Land and Jerusalem in 1857]. Moscow, Indrik Publ., 2007. $236 \mathrm{p}$.

9. Karashevich Nikanor Stefanovich. URL: http://www.rosgenea.ru. (accessed September 19, 2016).

10. Krestovozdvizhenskiy muzhskoy monastyr g. Starokonstantinova [Holy Cross Monastery in Starokonstantinov Town]. URL: http://www.azbuka.ru/ palomnik. (accessed September 19, 2016).

11. Latynov V.V. Slukhi: sotsialnye funktsii $i$ usloviya poyavleniya [Rumors: Social Functions and Conditions of Appearance]. URL: http://www. psyfactor.org/lib/rumors3htm. (accessed November 13, 2014).

12. Mertsalov E. Ot Petrozavodska do Ierusalima i obratno. Putevye zametki i vpechatleniya palomnika [From Petrozavodsk to Jerusalem and Back. Pilgrim's Travel Notes and Impressions]. Moscow, Indrik Publ., 2014. 256 p.

13. Norov A.S. Puteshestvie v Svyatuyu Zemlyu v 1835 godu [Journey to the Holy Land in 1835]. Moscow, Indrik Publ., 2008. 292 p.

14. Skalkovsky A. Russkoe obshchestvo parokhodstva $i$ torgovli. 1857-1869 gg. [Russian Steam Navigation and Trading Society. 1857-1869]. URL: http://www.odessitclub.org/publications/ almanac/alm_40/alm_6-19.pdf. (accessed September 16, 2016).

\section{Information about the Author}

Kirill E. Baldin, Doctor of Sciences (History), Professor, Head of Department of Russian History, Ivanovo State University, Gagarina St., 4, 153025 Ivanovo, Russian Federation, kebaldin@mail.ru, http://orcid.org/0000-0002-7568-0528.

\section{Информация об авторе}

Кирилл Евгеньевич Балдин, доктор исторических наук, профессор, заведующий кафедрой истории России, Ивановский государственный университет, ул. Гагарина, 4, 153025 г. Иваново, Российская Федерация, kebaldin@mail.ru, http://orcid.org/0000-0002-7568-0528. 